\title{
Australian Review Recommends Vouchers, but Government is Cautious
}

\section{Grant Harman}

Grant Harman is professor of educational management at the University of New England, and coordinating editor of the journal, Higher Education. Address: Department of Administration and Training, University of New England, Armidale NSW 2351 Australia. Fax: 61-026773363. E-mail: <gharman@metz.une.edu.au>.

A federal government-appointed review of higher education financing and policy has just released its final report. ${ }^{1}$ Among its key recommendations is one for the introduction of a student-centered funding model, or voucher scheme. Both the government and the opposition Labor Party have come out strongly against the introduction of a voucher scheme, however-at least in the short term.

Both political parties are understandably shy about making any commitment to a voucher scheme.

Both political parties are understandably shy about making any commitment to a voucher scheme. A federal election seems likely to be held before the end of 1998, and both sides are well aware that in the 1993 general election-which the conservative parties lost-a voucher scheme figured largely in the conservative education platform. In any case, it is widely believed that after the election, whoever wins office is likely to review the current funding system, and something along the lines of the market-driven model recommended by the review well might be implemented.

The review of higher education financing and policy was set up in late 1996 by then minister for employment, education and training, Senator Amanda Vanstone. It was chaired by Roderick West, a former Sydney private school headmaster, and its other members included one vice-chancellor, two professors (one of whom is also the chancellor of Australian National University), a public-sector economist, and two persons from industry.

The review was asked to broadly examine the higher education sector, provide a comprehensive policy framework for the future, and identify options for the financing of higher education teaching and research. It was the first broad national review of the higher education sector since the inquiry into education and training of the late 1970s chaired by Sir Bruce Williams - then vice-chancellor at the University of Sydney.

The review was supported by a small secretariat in the
Department of Employment, Education and Training (DEETYA). Its main sources of information were invited submissions, responses to the discussion paper it issued in late 1997, consultations with stakeholders, commissioned papers, and material prepared by the Higher Education Division of DEETYA. Almost 400 submissions were received from universities, associations, government agencies, business firms, and individuals, while almost 180 responses were received to the discussion paper. Both the submissions and responses were made publicly available on the review's home page, and so it was possible, for the first time, for anyone interested to have access to all the written input received.

In establishing the review, Senator Vanstone does not appear to have had very clear ideas about what she wanted to achieve. She was under pressure from the cabinet to make substantial cuts in funding for higher education, since the Howard government, which won office in March 1996, was committed to substantial reduction of public expenditure. She announced establishment of the review as part of her August 1996 budget statement - an attempt to pacify higher education interests, many of whom had been pressing for a review in the hope of securing some additional public funding and increased deregulation. In addition, Senator Vanstone was well aware of the work of the Dearing Committee in the United Kingdom and had hosted a meeting when Sir Ron Dearing who had visited Canberra.

\section{The review was asked to broadly ex- amine the higher education sector, pro- vide a comprehensive policy framework for the future, and identify options for the financing of higher education teach- ing and research.}

While it did not vary much from the general thrust of the discussion paper, the final report was a much superior document technically and attempted to address many of the criticisms made of the discussion paper. Publicly, both the discussion paper and final report were severely criticized, especially by key vice-chancellors and the National Tertiary Education Union. Privately, however, many university leaders expressed support for a number of the recommendations.

The review's vision for higher education was couched in terms of a strong commitment to lifelong learning and 
almost universal participation. It recommended that the government "declare its commitment to the establishment of a learning society in which all Australians, of whatever social, cultural or economic background, have access to postsecondary education of excellent value."

On this basis, it went on to recommend a funding and policy framework with these elements:

- a student-centered funding system with public contributions toward tuition costs driven by student choice for both undergraduates and research students, and with institutions able to set their own fee levels;

- more emphasis on priority setting and national coordination in research; and

- a more competitive and entrepreneurial higher education system, one better able to compete internationally and with the capacity to make investments in information technology and infrastructure.

\section{The review's vision for higher education was couched in terms of a strong com- mitment to lifelong learning and almost universal participation.}

Under the student-centered funding system, all school leavers and adults accessing postsecondary education for the first time would have a lifelong learning entitlement that could be used at an existing university, a Technical and Further Education (TAFE) college, or at a private university or Vocational Education and Training (VET) provider. Institutions would be able to set their own fees, and a Higher Education Contribution Scheme (HECS) loan system with repayment contingent on future income would be available to all students to allow deferment of payment of any tuition fees not covered by the government entitlement.

Almost immediately after the final report was released, David Kemp, minister for employment, education, and training, quickly distanced himself from key recommendations on the student entitlement system of funding and the freedom for institutions to set their own fee levels. More recently, in a carefully crafted speech given on April 21, 1998 to an OECD seminar in Sydney, he set out the government's agenda should it be returned to a second term. This has been interpreted as being meant to take the spotlight off the West Committee's report.

\section{Note}

1. Learning for Life: Final Report, Review of Higher Education Financing and Policy (Canberra: Department of Employment, Education and Training, 1998).

\section{Thailand's Economic Crisis Slows Down Public and Private Higher Education}

\section{Edward Vargo}

Edward Vargo is dean of the Faculty of Arts, Assumption University, Bangkok. Address: ABAC, Ramkhamhaeng 24, Bangkok 10240, Thailand. Fax 66-2-319-1936.E-mail: <artevg@au.ac.th>.

fter more than three decades of contentious disAcussion, Thailand's public universities have finally agreed to privatize by the year 2002. Reduced government funding is the engine behind this reform. Stateowned universities have suffered immediate cuts in budget (generally 20 to 30 percent) as the national budget itself was trimmed down two or three times in the past 12 months. The reductions affect not only operating expenses, but also faculty research and further training. Thus, units at public universities need to show reductions on bills for the use of paper, telephones, water, and electricity. A ban on the purchase of imported instrumentation is making the continuation of some research projects in science and technology next to impossible. No support is given for overseas conferences. Academic seminars and conferences cannot be organized on campus, within Bangkok, or up-country.

Thailand's public universities have finally agreed to privatize by the year 2002. Reduced government funding is the engine behind this reform.

In addition, there is a freeze on salary increases this year as well as talk of other cuts in pay. If the contract runs out for an existing expatriate professor, she or he will not be replaced with another foreigner. Because no replacements are planned for retiring staff either, openings for new jobseekers become very questionable. Young staff members are hit in still another way. Financial support for study abroad has been stopped until further notice. Those already on overseas scholarships are left stranded or encouraged to continue their studies at home. The one recent ray of hope for them was President Clinton's promise of scholarship assistance given to Prime Minister Chuan Leekpai during his March visit to Washington. As a result of all this retrenchment and the uncertainty it brings into their professional lives, 